\title{
LEKTUR MODERN SEJARAH PENDIDIKAN ISLAM DI INDONESIA
}

\author{
Salim \\ Fakultas Ilmu Tarbiyah dan Keguruan UIN Sumatera Utara \\ Jl. Willem Iskandar Pasar V Medan Estate, Medan, Sumatera Utara, 20371 \\ e-mail: salimuinsumedan@gmail.com
}

\begin{abstract}
Abstrak: Artikel ini bertujuan mendeskripsikan dan menganalisis delapan buku lektur sejarah pendidikan Islam modern karya-karya ilmuwan Muslim Indonesia. Temuan kajian ini adalah bahwa karya-karya tersebut membahas sejarah pendidikan Islam secara umum dari periode Rasul sampai Indonesia periode Orde Lama; paradigma pendidikan Islam hingga kontemporer; pertumbuhan dan pembaharuan pendidikan Islam. Ada juga karya yang merekonstruksi pendidikan Islam yang benar dan membahas dinamika pendidikan Islam secara luas tidak hanya di Indonesia namun juga di Asia Tenggara. Ada juga yang mengkaji berbagai pemikiran tokoh pendidikan Islam. Lalu karya lain mengkaji jaringan ulama Timur Tengah dan Kepulauan Nusantara dalam membentuk pendidikan yang Islami dan tentang zaman keemasan Islam, khususnya pendidikan. Semua lektur pendidikan ini sangat bermanfaat dalam menata ulang pendidikan Islami di Indonesia dan berkontribusi bagi kemajuan pendidikan Islam di masa mendatang.
\end{abstract}

\begin{abstract}
Modern Literature of the History of Islamic Education in Indonesia. This article aims to analyze eight literatures on the history of modern Islamic education by Indonesian Muslim scholars. The research finds that the first book discusses the history of Islam education in general from the period of the Prophet to the period of Indonesia Old Order regime, the classic to the contemporary paradigm of Islamic education to the contemporary, the growth and renewal of Islamic education; the dynamics of Islamic education in general not only in Indonesia but also in Southeast Asia region. Other books examine various thought of Islamic scholars of Islamic education as well as the golden age of Islam in various part, especially in the realm of education. The last book discussed is essential in rearranging Islamic education in Indonesia and contribute to the promotion of Islamic education in the future.
\end{abstract}

Kata Kunci: lektur, sejarah pendidikan Islam, modern, Indonesia 


\section{Pendahuluan}

Kajian sejarah pendidikan Islam adalah kajian sejarah pemberdayaan umat berdasarkan norma al-Qur'an dan hadis dalam konteks historis. Artinya, kajian sejarah pendidikan Islam, bukan sekadar menyangkut kronologi peristiwa-peristiwa yang terjadi, tetapi yang lebih penting adalah dampak peristiwa tersebut terhadap upaya pemberdayaan umat Islam, seperti dinamika munculnya gagasan-gagasan, aktualisasi gagasan dalam wujud tradisi intelektual atau keilmuan, dan format institusi pendidikan yang muncul. Ketiga indikator ini secara bersama-sama memola pendidikan, memberinya watak dan format, dan segi-segi lainnya yang berkembang dalam sejarah.

Namun sebelum lebih jauh mengkaji dan menelusuri beberapa literatur dalam sejarah pendidikan Islam ada baiknya mendefinisikan topik kajian ini terlebih dahulu agar dapat dimengerti dan dianalisa dengan baik. Kata sejarah secara etimologi dapat diungkapkan dalam bahasa Arab yaitu târîkh, berarti ilmu yang mengandung atau yang membahas penyebutan peristiwa dan sebab-sebab terjadinya peristiwa tersebut. Dalam bahasa Inggris, sejarah dapat disebut dengan history yang berarti uraian secara tertib tentang kejadiankejadian masa lampau (orderly description of past even). Adapun secara terminologi, sejarah berarti sejumlah keadaan dan peristiwa yang terjadi di masa lampau dan benar-benar terjadi pada diri individu dan masyarakat sebagaimana benar-benar terjadi pada kenyataan-kenyataan alam dan manusia. ${ }^{1}$ Sedangkan pengertian yang lain sejarah juga mencakup perjalanan hidup manusia dalam mengisi perkembangan dunia dari masa ke masa, karena sejarah mempunyai arti dan bernilai sehingga manusia dapat membuat sejarah sendiri dan sejarah pun membentuk manusia. ${ }^{2}$

Pendidikan Islam merupakan suatu proses bimbingan dari pendidik terhadap perkembangan jasmani, rohani, dan akal peserta didik ke arah terbentuknya pribadi Muslim yang baik. ${ }^{3}$ Karena ia merupakan alat yang dapat difungsikan untuk mengarahkan pertumbuhan dan perkembangan hidup manusia (sebagai makhluk pribadi dan sosial) kepada titik optimal kemampuannya untuk memperoleh kesejateraan hidup di dunia dan kebahagiaan hidup di akhirat. Dalam hal ini, kedayagunaan pendidik sebagai alat pembayaran sangat bergantung pada pemegang alat kunci yang banyak menentukan keberhasilan proses pendidikan, ${ }^{4}$ yang telah berkembang di berbagai daerah dari sistem yang paling sederhana menuju sistem pendidikan Islam yang modern. Dalam perkembangan pendidikan Islam, dalam sejarahnya menunjukan perkembangan dalam subsistem yang bersifat operasional dan

\footnotetext{
h. 1 .

${ }^{1}$ Hasbullah, Sejarah Pendidikan Islam di Indonesia (Jakarta: Raja Grafindo Persada, 1995),

${ }^{2}$ Departemen Agama, Rekontruksi Sejarah Pendidikan Islam di Indonesia (Jakarta: Departemen Agama RI, 2005), h. 1.

${ }^{3}$ A. Mustafa, Sejarah Pendidikan Islam di Indonesia (Bandung: Pustaka Setia, 1999), h. 11.

${ }^{4}$ Armai Arief, Sejarah Pertumbuhan dan Perkembangan Lembaga Pendidikan Islam Klasik (Bandung: Percetakan Angkasa, 2005), h. 4.
} 
teknis terutama tentang metode, alat-alat dan bentuk kelembagaan adapun hal yang menjadi dasar dan tujuan pendidikan Islam tetap dapat dipertahankan sesuai dengan ajaran Islam dalam al-Qur'an dan Sunnah. ${ }^{5}$ Pendidikan Islam menurut Zakiah Drajat merupakan pendidikan yang lebih banyak ditunjukkan kepada perbaikan sikap mental yang akan terwujud dalam amal perbuatan, baik bagi keperluan diri sendiri maupum orang lain yang bersifat teoretis dan praktis. ${ }^{6}$

Dari berbagai pengertian pendidikan Islam dapat disimpulkan bahwa pendidikan Islam adalah proses bimbingan dari pendidik yang mengarahkan anak didiknya kepada perbaikan sikap mental yang akan terwujud dalam amal perbuatan dan terbentuknya pribadi Muslim yang baik.

Dari pengertian sejarah dan pendidikan Islam dapat dirumuskan pengertian tentang sejarah pendidikan Islam atau Târîkh al-Tarbiyah al-Islâmiyah. Pertama, keterangan mengenai pertumbuhan dan perkembangan pendidikan Islam dari waktu ke waktu yang lain, sejak zaman lahirnya Islam sampai dengan masa sekarang. Kedua, cabang ilmu pengetahuan yang berhubungan dengan pemunbuhan dan perkembangan pendidikan Islam, baik dan segi ide dan konsepsi maupun segi institusi dan operasionalisasi sejak zaman Nabi Muhammad SAW. sampai sekarang. ${ }^{7}$ Hasbullah merumuskan bahwa sejarah pendidikan Islam. Pertama, catatan peristiwa tentang pertumbuhan dan perkembangan pendidikan Islam dari sejak lahirnya sampai sekarang. Kedua, suatu cabang ilmu pengetahuan yang berhubungan dengan pertumbuhan dan perkembangan pendidikan Islam baik dari segi gagasan atau ide-ide, konsep, lembaga maupun operasionalisasi sejak zaman Nabi Muhammad hingga saat ini. ${ }^{8}$ Dari dua sumber yang merumuskan sejarah pendidikan Islam dapat disimpulkan bahwa kedua penjelasan memiliki maksud yang sama yaitu peristiwa atau cabang ilmu pengetahuan mengenai pertumbuhan dan perkembangan pendidikan Islam dari segi ide, konsep, lembaga operasionalisasi dari sejak zaman Nabi Muhammad SAW. sampai sekarang.

Obyek kajian sejarah pendidikan Islam adalah fakta-fakta pendidikan Islam berupa informasi tentang pertumbuhan dan perkembangan pendidikan Islam baik formal, informal dan non formal. Dengan demikian akan diperoleh apa yang disebut dengan sejarah serba objek hal ini sejalan dengan peranan agama Islam sebagai agama dakwah penyeru kebaikan, pencegah kemungkaran, menuju kehidupan yang sejahtera lahir batin secara material dan spiritual. Namun sebagai cabang dari ilmu pengetahuan, objek sejarah pendidikan Islam umumnya tidak jauh berbeda dengan yang dilakukan dalam objek-objek sejarah pendidikan, seperti mengenai sifat-sifat yang dimilikinya. Dengan kata lain, bersifat menjadi sejarah serba subjek. ${ }^{9}$

\footnotetext{
${ }^{5}$ A. Mustafa, Sejarah Pendidikan Islam, h.11.

${ }^{6} \mathrm{http} / /$ forum.dudung.net. 2.

7Zuhairini, et al. Sejarah Pendidikan Islam (Jakarta: Bumi Aksara, 1997), h. 2.

${ }^{8}$ Hasbullah, Sejarah Pendidikan Islam, h. 8-9.

${ }^{9}$ Mustafa, Sejarah Pendidikan Islam di Indonesia, h. 14.
} 
Untuk memahami sejarah pendidikan Islam diperlukan suatu pendekatan atau metode yang bisa ditempuh adalah keterpaduan antara metode deskriptif, metode komparatif dan metode analisis sistensis. Dengan metode deskriptif, ajaran-ajaran Islam yang dibawa oleh Rasulullah SAW., yang termaktub dalam al-Qur'an dijelaskan oleh Sunnah, khususnya yang langsung berkaitan dengan pendidikan Islam dapat dilukiskan dan dijelaskan sebagaimana adanya. Pada saatnya dengan cara ini, yang terkandung dalam ajaran Islam dapat dipahami. Metode komparatif mencoba membandingkan antara tujuan ajaran Islam tentang pendidikan dan tuntunan fakta-fakta pendidikan yang hidup dan berkembang pada masa dan tempat tertentu. Dengan metode ini dapat diketahui persamaan dan perbedaan yang ada pada dua hal tersebut sehingga dapat diajukan pemecahan yang mungkin keduanya apabila terjadi kesenjangan. Metode analisis sintesis digunakan untuk memberikan analisis terhadap istilah-istilah atau pengertian-pengertian yang diberikan ajaran Islam secara kritis, sehingga menunjukkan kelebihan dan kekhasan pendidikan Islam. Pada saatnya dengan metode sintesis dapat diperoleh kesimpulan-kesirnpulan yang akurat dan cermat dari pembahasan sejarah pendidikan Islam. Metode ini dapat pula didayagunakan untuk kepentingan proses pewarisan dan pengembangan budaya umat manusia yang Islami. ${ }^{10}$

Dengan mengkaji sejarah akan bisa memperoleh informasi tentang pelaksanaan pendidikan Islam dari zaman Rasulullah SAW. sampai sekarang mulai dari pertumbuhan, perkembangan, kemajuan, kemunduran, dan kebangkitan kembali tentang pendidikan Islam. Dari sejarah dapat diketahui segala sesuatu yang terjadi dalam penyelenggaraan pendidikan Islam dengan segala ide, konsep, institusi, sistem, dan operasionalisasinya yang terjadi dari waktu ke waktu, jadi sejarah pada dasarnya tidak hanya sekadar memberikan romantisme tetapi lebih dari itu merupakan refleksi historis. Dengan demikian, belajar sejarah pendidikan Islam dapat memberikan semangat (back projecting theory) untuk membuka lembaran dan mengukir kejayaan dan kemajuan pendidikan Islam yang baru dan lebih baik. Dengan demikian, sejarah pendidikan, Islam sebagai studi tentang masalah-masalah yang berhubungan dengan sejarah pendidikan sudah barang tentu sangat bermanfaat terutama dalam rangka memberikan sumbangan bagi pertumbuhan atau perkembangan pendidikan. ${ }^{11}$

Secara umum, sejarah memegang peranan penting bagi kehidupan umat manusia. Hal ini karena sejarah menyimpan atau mengandung kekuatan yang dapat menimbulkan dinamisme dan melahirkan nilai-nilai baru bagi pertumbuhan serta perkembangan kehidupan umat manusia. Sumber utama ajaran Islam (al-Qur'an) mengandung cukup banyak nilainilai kesejarahan yang langsung dan tidak langsung mengandung makna benar, pelajaran yang sangat tinggi dan pimpinan utama khususnya umat Islam. Ilmu sejarah dalam Islam menduduki arti penting dan berguna dalam kajian dalam Islam. Oleh karena itu, kegunaan h. 14-15.

${ }^{10}$ Enung K. Rukiati, Sejarah Pendidikan Islam di indonesia (Bandung: Pustaka Setia, 2006),

${ }^{11}$ Departemen Agama, h. 18. 
sejarah pendidikan meliputi dua aspek yaitu kegunaan yang bersifat umum dan yang bersifat akademis. ${ }^{12}$ Ilmu sejarah berusaha menafsirkan pengalaman masa lampau manusia dalam berbagai kegiatan. Akan tetapi, sejalan dengan perkembangan bahwa tidak semua kegiatan manusia berjalan mulus, terkadang menemukan rintangan-rintangan tertentu, sehingga dalam proses kegiatannya mendapat sesuatu yang tidak diharapkan, maka perlu bercermin atau dengan kata lain mengambil pelajaran dari kejadian-kejadian masa lampau sehingga târîkh itu bagi masa menjadi cermin dan dapat diambil manfaatnya khususnya bagi perkembangan pendidikan Islam.

Sebagai pembanding, suatu peristiwa yang berlangsung dari masa ke masa tentu memiliki kesamaan dan kekhususan. Dengan demikian, hasil proses pembanding antara masa silam, sekarang, dan yang akan datang, diharapkan dapat memberi andil bagi perkembangan pendidikan Islam, karena sesungguhnya sejarah itu menjadi cermin perbandingan bagi masa yang baru. Sebagai perbaikan, setelah berusaha menafsirkan pengalaman masa lampau manusia dalam berbagai kegiatan, berusaha pula untuk memperbaiki keadaan yang sebelumnya kurang konstruktif menjadi lebih konstruktif. ${ }^{13}$

Adapun kegunaan sejarah pendidikan Islam yang bersifat akademis diharapkan dapat mengetahui dan memahami pertumbuhan dan perkembangan pendidikan Islam, sejak zaman lahirnya sampai masa sekarang, mengambil manfaat dari proses pendidikan islam, guna memecahkan problematika pendidikan Islam pada masa kini, dan memiliki sikap positif terhadap perubahan-perubahan dan pembaharuan-pembaharuan sistem pendidikan Islam. Selain itu, sejarah pendidikan Islam akan mempunyai kegunaan dalam rangka pembangunan dan pengembangan pendidikan Islam. Dalam hal ini, sejarah pendidikan Islam akan memberikan arah kemajuan yang pernah dialami, sehingga pembangunan dan pengembangan itu tetap berada dalam kerangka pandangan yang utuh dan mendasar. ${ }^{14}$

Kitab-kitab sejarah Islam klasik ditulis dalam berbagai versi seperti sîrah, ayyâm, tarâjim, thabaqat, tarîkh, manâqib, dan hikayat. Sementara literatur sejarah Islam pada masa kontemporer ini khususnya yang berkenaan dengan pendidikan kelihatannya lebih difokuskan dalam objek tertentu atau aspek tertentu.

Secara khusus, artikel ini akan menelaah lektur sejarah pendidikan Islam modern. Artikel ini akan mengulas delapan buku sejarah pendidikan Islam karya para ilmuwan Muslim Indonesia yang ditulis dan diterbitkan dalam bahasa Indonesia. Secara metodologis, artikel ini menggunakan metode analisis deskriptis, dan merupakan studi kepustakaan.

\footnotetext{
${ }^{12}$ A. Mustafa, Sejarah Pendidikan Islam di Indonesia, h. 16.

${ }^{13}$ Rukiati, Sejarah Pendidikan Islam di Indonesia, h. 17.

${ }^{14}$ Zuhairini, et al. Sejarah Pendidikan Islam, h. 2.
} 


\section{Khazanah Lektur Sejarah Pendidikan Islam Modern}

Khazanah lektur sejarah pendidikan Islam modern tidak kalah kayanya dengan khazanah klasik, karena banyaknya para intelektual Muslim yang concern dalam bidang kajian sejarah pendidikan Islam, apalagi pendidikan tersebut begitu sangat urgen pada masa sekarang ini. Berikut akan ditelaah delapan karya dalam bidang sejarah pendidikan Islam di era Indonesia modern.

\section{Sejarah Pendidikan Is/am ${ }^{15}$}

Buku dengan judul Sejarah Pendidikan Islam terdiri atas 21 bab, dan diterbitkan pada tahun 2007 oleh Kencana Perdana Media Group di Jakarta yang terdiri atas 360 halaman. Buku yang diedit oleh Samsul Nizar ini merupakan kumpulan tulisan tentang sejarah pendidikan Islam dari beberapa penulis dengan menelusuri jejak sejarah pendidikan dari era Rasulullah sampai Indonesia. Dalam kata pengantar, Nizar menerangkan quo vadis pendidikan Islam di Indonesia, menelusuri sejarah menuju paradigma pendidikan berkualitas. Dalam pembahasan ini, diterangkan kondisi pendidikan nasional yang serba dengan kekurangan dan direfleksikan kepada sejarah pendidikan Islam untuk memperbaiki sistem pendidikan nasional ke arah yang lebih maju.

Dalam bab I, diulas tentang profil Rasulullah SAW. sebagai pendidik ideal: telaah pola pendidikan Islam era Rasulullah fase Makkah dan Madinah yang ditulis oleh Zainal Efendi Hasibuan yang menerangkan tentang kondisi politik, sosio kultural pra Islam sampai fase awal Islam, dan bagaimana pendidikan pada zaman Rasulullah SAW. mulai dari lembaga pendidikannya, materi dan kurikulum serta metode pengajaran, dan evaluasi era Rasulullah SAW. Rasulullah sebagai pendidik yang ideal dapat dilihat dari sejumlah indikator, dan walaupun dengan sarana dan prasarana yang terbatas dapat menelurkan para intelektual yang berkualitas. Padahal sebelumnya bangsa Arab masih terkungkung dalam kegelapan dan kejahiliahan melesat ke arah peradaban yang tinggi. Metode yang diterapkan Rasulullah SAW. sangat bervariasi sehingga dapat menghilangkan kejenuhan. Rasulullah SAW. mendidik para sahabat dengan menjadikan dirinya sebagai suri teladan. Adapun kurikulum yang digunakan Rasulullah SAW. adalah kurikulum berbasis masyarakat. Hal tersebut dapat dilihat dari pembagian pengajaran era Makkah dan era Madinah.

Dalam bab II, diulas tentang pola pendidikan Islam pada periode Rasulullah SAW. di Makkah dan Madinah. Bagian ini ditulis oleh Khamaruzzaman yang membahas kondisi sosial kultural Makkah dan Madinah pada era Rasulullah SAW. dan pola yang dilakukannya dalam mengajarkan tauhid kepada para sahabat. Kurikulum yang digunakan yaitu berlandaskan al-Qur'an dan hadis.

\footnotetext{
${ }^{15}$ Syamsul Nizar, Sejarah Pendidikan Islam (Jakarta: Kencana Perdana Media Group, 2007).
} 
Dalam bab III, dibahas tentang pola pendidikan Islam pada masa Khulafâ' al-Râsyiîdin yang ditulis oleh Mhd. Dalpen. Bagian ini menerangkan keadaan dan sistem pendidikan di zaman Khulafâ' al-Râsyiîdin. Pada zaman Abû Bakar, sistem pendidikannya tidak jauh berbeda dari pendidikan pada masa Rasulullah. Pada masa 'Umar, pendidikan sudah lebih meningkat di mana para guru sudah diangkat dan digaji dari bait al-mâl untuk mengajar ke daerah-daerah yang baru ditaklukkan. Pada masa 'Utsmân bin 'Affân ra., pendidikan diserahkan pada rakyat, dan sahabat tidak hanya fokus di Madinah tetapi juga dikirim ke daerah lain. Pada masa 'Ali ra., pendidikan kurang mendapat perhatian karena terjadi pergolakan dan konflik yang menimbulkan kekacauan.

Dalam bab IV, diulas pola pendidikan Islam pada periode Dinasti Umayyah yang ditulis oleh Silvianti Candra. Bagian ini membahas tentang pembentukan Dinasti Umayyah, kemajuan yang dicapai olehnya, pola pendidikan, dan pusat pendidikannya. Pada masa ini, berkembang ilmu-ilmu agama Islam dan adanya pembukuan hadis pada zaman 'Umar bin 'Abd al-Azîz.

Dalam bab V, diulas pola pendidikan Islam pada periode Dinasti 'Abbasiyah yang ditulis oleh Ali Nupiah. Bagian ini membahas sejarah pendirian Dinasti 'Abbasiyah, sistem politik, pemerintahan, bentuk negara, dan sistem sosialnya. Pada zaman ini, Islam mencapai puncak kejayaan yang dapat dilihat dari indikator seperti kemajuan dalam bidang sains dan teknologi. Puncak kejayaan tersebut terjadi pada masa khalifah Harun al-Râsyid.

Dalam bab VI, diulas pola pendidikan Islam di Spanyol era awal yang ditinjau dari aspek historis filosofis yang ditulis oleh Samsul Nizar. Dalam tulisan ini, dibahas tentang sejarah awal Islam Spanyol, perkembangan pendidikan dan kebudayaan Spanyol Islam beserta faktor penunjangnya, dan dampak pendidikan Spanyol Islam bagi perkembangan dunia Barat modern. Bagian ini menerangkan bahwa Spanyol merupakan pintu penghubung antara dunia Islam dan Eropa, dan dari wilayah ini lah proses pencerahan Eropa mulai dibentuk.

Pada bab-bab yang selanjutnya diterangkan "Sejarah Pendidikan Islam dari Pendidikan Islam di Andalusia" oleh Yusmanto, "Lembaga-Lembaga Pendidikan Islam Era Awal" oleh Mira Astuti, "Kurikulum dan Pola Perkembangan Ilmu Pengetahuan pada Masa Klasik hingga Masa Keemasan" oleh Sondal Pramujaya, "Transformasi dan Kontribusi Intelektual Islam atas Dunia Barat" oleh Farida Syam, "Madrasah Nizamiyah: pengaruhnya terhadap Perkembangan Pendidikan Islam dan Aktivitas Ortodoksi Sunni" oleh Edi Warman, "Pendidikan Islam pada Era Kemunduran" oleh Mulyadi Hermanto Nasution, "Kehancuran Dinasti 'Abbasiyah dan Pengaruhnya terhadap Pelaksanaan Pendidikan di Dunia Islam” oleh Roli Yandri, "Sejarah dan Perkembangan Arsitektur Islam Dinasti Usmaniyah" oleh Samsul Nizar, "Dinamika Sejarah Pendidikan Perempuan Potret Timur Tengah dan Indonesia Era Awal" oleh Wahyu Hikmah, "Dikotomi Ilmu pengetahuan: Akar Tumbuhnya Dikotomi Ilmu dalam Peradaban Islam" oleh Yudelasharmi, "Muhammad 'Abduh dan Usaha Pembaruan Pendidikan Islam di Mesir" oleh Yasmansyah, "Gagasan Islamisasi Ilmu Pengetahuan dan Implikasinya dalam Pendidikan" oleh Ahmad Syarifin, "Sejarah dan Dinamika Lembaga-Lembaga Pendidikan 
Islam Nusantara" oleh Abasri, "Pola Kebijakan Pendidikan Islam di Nusantara pada Masa Awal sampai Sebelum Kemerdekaan" oleh Maswardi, "Organisasi Sosial Keagamaan dan Pendidikan Islam" oleh Muhammad Syaifudin, dan "Pola dan Kebijakan Pendidikan Islam pada Masa Awal Kemerdekaan sampai pada Orde Lama” oleh Zulhandra.

Dari konten buku, diterangkan secara mendalam tentang sejarah pendidikan Islam dari era Rasulullah SAW. hingga Islam di Indonesia pada masa orde lama. Dengan bahasa penulisan yang apik, penulis mengajak pembacanya untuk berdiskusi dan didapatkan analisis dan riset yang jarang ditemukan. Dikarenakan buku ini merupakan kumpulan dari sejumlah makalah, pembahasan yang disampaikan kurang runtut dan sistematis, sehingga agak menyulitkan para pembaca untuk mengikuti alurnya, dan di dalamnya terkadang ada dua pembahasan yang sama.

\section{Pendidikan Islam dari Paradigma Klasik hingga Kontemporer ${ }^{16}$}

Buku ini berjudul Pendidikan Islam: dari paradigma klasik hingga Kontemporer yang ditulis oleh Tim Dosen Fakultas Tarbiyah UIN Maulana Malik Ibrahim Malang dan diterbitkan oleh UIN-Malang Press pada September 2009 dengan ketebalan 410 halaman. Buku ini menggambarkan dalam kehidupan sosial, institusi pendidikan baik umum maupun Islam, dan tugas suci untuk mengemban misi mulia agar membenahi kualitas hidup manusia jadi lebih baik, suatu misi kemanusiaan yang sangat bermanfaat dalam rangka membentuk sikap mental lulusan yang berperadaban dan menjunjung tinggi nilai kemanusiaan.

Secara filosofis, tujuan pendidikan adalah untuk mengembangkan potensi manusia ke arah yang maksimal dan lebih maju. Sebab, potensi yang diberikan oleh Allah SWT. tidak akan berkembang dengan sendirinya tanpa terpenuhinya pendidikan yang memadai. Pendidikan yang dimaksud di sini mencakup aspek jasmani maupun ruhani, seperti spiritual dan nilai-nilai etis.

Pendidikan Islam harus menjadi kekuatan (power) yang ampuh untuk menghadapi wacana kehidupan yang lebih krusial. Ketika globalisasi menjadi bagian dari kehidupan manusia, persoalan-persoalan baru muncul dengan aneka ragam bentuknya. Tantangan semacam itu harus direspons secara apresiatif agar pendidikan tidak dikatakan sebagai out of date (ketinggalan zaman).

Refleksi pemikiran dan rumusan persoalan pendidikan Islam harus bernafaskan kekinian (up to date). Jika dipandang secara historis, memang adanya suatu kejadian yang telah lalu, dapat dijadikan sebuah pelajaran untuk menjadi lebih baik lagi, tapi jangan sampai melupakan perhatian yang perlu diberikan di masa kini dan masa mendatang.

Pendidikan Islam harus menjadi terobosan baru untuk membentuk pola hidup umat

\footnotetext{
${ }^{16}$ Team Dosen Fakultas Tarbiyah UIN Maulana Malik Ibrahim, Pendidikan Islam dari Paradigma Klasik Hingga Kontemporer (Malang: UIN MALANG Press, 2009).
} 
yang lebih maju dan terbebas dari kebodohan dan kemiskinan. Sebab secara filosofi yang sudah tidak asing lagi untuk diketahui bahwa antara kebodohan dan kemiskinan itu merupakan dua sifat manusia yang mengkristal dan menjadi musuh bebuyutan pendidikan.

Di dalam al-Qur'an telah disebutkan dengan jelas dan gamblang bahwa manusia selalu diingatkan untuk selalu berlomba-lomba dalam hal kebaikan, yaitu memperhatikan hal-hal apa yang harus dilakukan untuk hari esok dan di masa yang akan datang. Hal ini dimaksudkan agar setiap aktivitas yang akan dilakukan selayaknya memperhatikan apa yang menjadi hal terbaik di masa depan, mempunyai pandangan yang progresif serta dapat ditempuh oleh masing-masing individu, manakala semua itu dilakukan dengan melakukan pengembangan atau pengembangan menjadi lebih maju.

Mencermati hal tersebut, pendidikan Islam saat ini perlu dipandang secara holistik. Dengan melihat pendidikan Islam secara holistik pada akhirnya akan menjadi paradigma baru yang kontekstual dan adaptif terhadap perubahan zaman. Karena itu, pendidikan Islam harus selalu merekonstruksi secara terus-menerus dan jangan sampai berhenti untuk mengerjakan sesuatu yang terbaik bagi masa depan.

Buku yang telah diresensi ini merupakan kumpulan dari beberapa penulis yang telah disusun menjadi tiga bagian. Bagian pertama membahas tentang redesain pendidikan Islam masa depan. Secara kritis pada bagian tersebut, penulis mencoba menyajikan elaborasi terhadap konsep-konsep pendidikan Islam yang selama ini belum banyak dikembangkan. Dua artikel tentang orientasi pengembangan pembelajaran pendidikan agama Islam di perguruan tinggi dan paradigma pendidikan sufistik sebagai alternatif pengembangan kepribadian, merupakan tulisan pembuka dari buku ini.

Di bagian kedua, penulis mengetengahkan masalah revitalisasi model lembaga pendidikan Islam. Pada pokok bahasan ini, diulas secara gamblang tentang pentingnya pendidikan di lingkungan keluarga, sekolah, dan pesantren di tengah kehidupan global. Akar-akar sejarah Islam, khususnya dalam konteks Indonesia, tidak hanya memberikan kualitas peradaban umat Islam. Akan tetapi, lebih dari itu, memberikan model pendidikan yang relevan sesuai dengan tuntutan zaman.

Pada bagian terakhir dijelaskan seputar reinventing pemikiran pendidikan Islam. Selain upaya untuk merancang masa depan pendidikan Islam yang ideal, salah satu caranya adalah mencontoh pengalaman, pemikiran atau pengetahuan dari para tokoh terdahulu, sebagai acuan atau landasan untuk berkembang lebih maju lagi. Di dalam buku ini telah disediakan beberapa pendapat rnenurut para tokoh Islam, sehingga pembaca tidak perlu susah-susah mencari beberapa referensi. Pembaca hanya tinggal membaca dan menghayati kandungannya.

Buku ini dapat dinikmati semua kalangan remaja dan dewasa, khususnya yang membidangi disiplin ilmu pendidikan Islam atau yang sedang menyelesaikan studi di Fakultas Tarbiyah dan Keguruan. Banyak penulis yang dilibatkan dalam pembuatan buku. Karena itu, 
isi dan gaya tulisannya tidak sinkron. Meskipun begitu, diharapkan semua pembaca dapat menikmati dan mengerti isinya.

\section{Sejarah Pertumbuhan dan Pembaruan Pendidikan Islam di Indonesia ${ }^{17}$}

Buku ini berjudul Sejarah Pertumbuhan dan Pembaruan Pendidikan Islam di Indonesia yang ditulis oleh Haidar Putra Daulay, dan diterbitkan Kencana Prenada Media Group pada Agustus 2007 dengan ketebalan 192 halaman. Dalam buku ini dideskripsikan tentang sejarah masuknya Islam di Indonesia. Keunikannya terlihat kepada proses masuknya Islam ke Indonesia yang relatif berbeda dengan daerah lain. Islam masuk ke Indonesia secara damai dibawa oleh para pedagang dan mubaligh. Sedangkan Islam yang masuk ke daerah lain pada umumnya banyak lewat penaklukan, seperti masuknya Islam ke Irak, Iran (Persia), Mesir, Afrika Utara sampai ke Andalusia.

Dijelaskan bahwa saluran proses islamisasi di Indonesia yaitu perdagangan, perkawinan, kesenian, sufisme, dan pendidikan. Terbentuknya masyarakat Muslim di suatu tempat adalah melalui proses yang panjang, yang dimulai dari terbentuknya pribadipribadi Muslim sebagai hasil dari upaya para dai. Masyarakat Muslim tersebut selanjutnya menumbuhkan kerajaan Islam.

Haidar menjelaskan bahwa pendidikan Islam di Indonesia telah berlangsung sejak masuknya Islam ke Indonesia. Pada tahap awal pendidikan Islam dimulai dari kontak pribadi maupun kolektif antara mubaligh dengan peserta didiknya. Setelah komunitas Muslim terbentuk di suatu daerah, maka mulailah mereka membangun masjid, yang difungsikan sebagai tempat ibadah dan pendidikan. Inti dari materi pendidikan pada masa awal tersebut adalah ilmu-ilmu agama yang dikonsentrasikan dengan membaca kitab-kitab klasik. Kitabkitab ini adalah menjadi ukuran bagi tinggi rendahnya ilmu agama seseorang. Pendidikan Islam yang sederhana ini sangat kontras dengan pendidikan Barat yang dibangun oleh pemerintah kolonial Belanda pada abad ketujuh belas.

Haidar menjelaskan bahwa pada awal abad kedua puluh, muncul ide-ide pembaruan pendidikan Islam di Indonesia yang didorong oleh sejumlah hal berikut. Pertama, daya dorong dari ajaran Islam itu sendiri yang mendorong umat Islam untuk memotivasi umatnya guna melakukan pembaruan (tajdîd), dan juga kondisi umat Islam Indonesia yang jauh tertinggal dalam bidang pendidikan. Kedua, daya dorong yang muncul dari para pembaru pemikir Islam yang diinspirasi dari berbagai tokoh-tokoh pembaru pemikiran Islam seperti Jamal al-Dîn al-Afghânî, Muhammad 'Abduh, dan Muhammad Rasyid Ridha.

Menurut Haidar, perjalanan sejarah pendidikan Islam di Indonesia hingga saat sekarang ini telah melalui tiga periodesasi. Pertama, periode awal sejak kedatangan Islam

\footnotetext{
${ }^{17}$ Haidar Putra Daulay, Sejarah Pertumbuhan dan Pembaruan Pendidikan Islam di Indonesia (Jakarta: Kencana Perdana Media Group, 2007).
} 
ke Indonesia sampai masuknya ide-ide pembaruan pemikiran Islam awal abad kedua puluh. Periode ini ditandai dengan pendidikan Islam yang terkonsentrasi di pesantren, dayah, surau atau masjid dengan titik fokus adalah ilmu-ilmu agama yang bersumber dari kitab-kitab klasik. Kedua, periode ini telah dimasuki oleh ide-ide pembaruan pemikiran Islam pada awal abad kedua puluh. Periode ini ditandai dengan lahirnya madrasah, dan juga telah memasukkan matapelajaran umum ke dalam program kurikulum, serta telah mengadopsi sistem pendidikan modern, seperti metode, manajerial, dan klasikal. Ketiga, pendidikan Islam telah terintegrasi ke dalam sistem pendidikan nasional sejak lahirnya Undang-Undang No. 2 Tahun 1989 dan Undang-Undang No. 20 Tahun 2003. Sejak pemberlakukan Undang-Undang Sistem Pendidikan Nasional (UU No. 2 tahun 1989) yang kemudian dilengkapi dengan beberapa Peraturan Pemerintah, dan diperkuat pula dengan Undang-Undang No. 20 tahun 2003, maka jelaslah bahwa pendidikan di Indonesia telah diatur oleh satu peraturan yang telah disepakati.

Menurut Haidar, pendidikan Islam yang dimaknai sebagai matapelajaran dan lembaga telah mendapat kedudukan dalam sistem pendidikan nasional. Bab-bab dan pasal-pasal serta ayat-ayat yang tercantum dalam PP 28, 29 Tahun 1990, serta PP 72, 73 Tahun 1991, PP 38, 39 Tahun 1992 dan PP 60 Tahun 1999, dan dalam Undang-Undang No. 20 Tahun 2003, Pasal 12, 17, 18, 20, 26, 27, 28, dan Pasal 30 telah menggambarkan betapa pendidikan Islam telah duduk dalam sistem pendidikan nasional yang dengan demikian kedudukannya adalah merupakan satu kesatuan yang tidak terpisahkan dari sistem pendidikan nasional.

\section{Islam: Percikan Sejarah, Filsafat, Politik, Hukum dan Pendidikan ${ }^{18}$}

Buku ini berjudul Islam: Percikan Sejarah, Filsafat, Politik, Hukum dan Pendidikan ditulis oleh Yudian Wahyudi dan diterbitkan oleh Pesantren Nawesea Pres Yogyakarta pada tahun 2011 dengan ketebalan 164 halaman. Buku ini mendeskripisikan bahwa akhir-akhir ini Islam dipahami sepotong-potong oleh sebagian umatnya. Karena pemahaman yang tidak utuh, Islam yang dipahami menjadi Islam yang begitu menakutkan. Wajah Islam menjadi suram dan mengerikan. Berbagai tindak kekerasan malah dialamatkan sebagai ajaran Islam. Karena itulah, pemahaman yang sepotong perlu dijernihkan kembali. Menurut Yudian, bila masih dibiarkan, pemahaman itu justru akan merusak keindahan Islam sendiri. Di situlah perlu sebuah pengantar yang jernih dalam membaca Islam. Jernih bukan sekadar kritis, tetapi juga memberikan inspirasi kebangkitan dan kemajuan Islam untuk mengisi peradaban dunia. Nilai-nilai ajaran Islam sangat ditunggu untuk menyemai kembali wajah peradaban yang sedang kusam.

Menurut Yudian, peradaban Islam bukanlah warisan yang diterima secara taken for granted, apa adanya, tanpa ada upaya penjernihan ulang, reaktualisasi dan kontekstualisasi

\footnotetext{
${ }^{18 Y u d i a n}$ Wahyudi, IsIam: Percikan Sejarah, Filsafat, Politik, Hukum dan Pendidikan (Yogyakarta: Pesantren Nawesea Press, 2011).
} 
atas warisan tersebut. Peradaban Islam yang agung itu lahir dengan jejak penuh getir, hasil ramuan para filosof, teolog, fukaha, sastrawan, dan para negarawan. Semua saling berakit melakukan beragam gerakan penuh terobosan dalam berbagai segi kehidupan, utamanya ilmu pengetahuan, ekonomi, politik dan pendidikan. Warisan peradaban Islam ini tak lain merupakan manifestasi mukjizat terbesar yang diberikan Allah kepada umat Islam: iqra' (bacalah).

Menurut Yudian, mukjizat iqra' inilah yang menjadi arus pengantar kajian yang dikemukakan dalam buku ini. Buku ini bukan sekadar memberikan "pengantar kajian" dalam Islamic Studies, karena spirit keilmuan yang dikemukakan penulis dalam buku ini memberikan ledakan keilmuan yang membuat pembaca bisa jadi tercengang-cengang. Teror wacana yang diusung Yudian benar-benar akan menjadikan pembaca "merinding", sehingga segera bangkit memberikan apresiasi lebih lanjut dalam memahami apa itu Islam. Yudian mengajak pembaca tidak hanya "berhenti" dalam pengantar ini, melainkan semakin keranjingan dalam meledakkan potensi membaca dan membangkitkan pembaca untuk melakukan torehan prestasi yang bisa mencengangkan dunia.

Belajar dari warisan peradaban Islam masa silam, Yudian menjadikan spirit Iqra' sebagai pendobrak awal untuk memulai sebuah petualangan intelektual. Membaca akan mengajak pembaca untuk melakukan petualangan ke segala penjuru semesta pengetahuan tanpa batas. Aktivitas membaca juga berhak dilakukan siapa saja, tanpa peduli latar belakangnya. Spirit iqra' pula yang telah dibuktikan Yudian melakukan pengembaraan intelektual dengan mengkhutbahkan Islam di berbagai penjuru benua, mulai Eropa, Australia. Afrika, dan Asia. Iqra', sekali lagi, merupakan "pengantar" menuju pencerahan bagi peradaban umat manusia.

Percikiran "pengantar" dalam buku ini memberikan inspirasi bagi pembaca bahwa ledakan iqra' telah menelurkan para pemikir Islam yang memberikan sumbangsih sangat besar bagi kemajuan peradaban dunia. Muhammad bin Idrîs al-Syâfiii, misalnya, merupakan pemikir yang berjasa besar bagi perkembangan kajian hukum Islam (Islamic law). Al-Syâfii mampu membangun kompromi pemikiran moderat yang mensinergikan peradaban teks di Madinah dengan peradaban rasio di Irak. Dengan berdomisili di Mesir yang masih berkembang zaman itu, al-Syâfi'i mampu membangun poros keilmuan moderat yang bisa memberikan jalan alternatif bagi perkembangan keilmuan di negara berkembang.

Bisa dikatakan bahwa al-Syâfi'i merupakan bapak konstutuasionalisme dalam kajian Islamic law. Ini tak lain karena spirit keilmuan yang menancap dalam diri al-Syâfíi begitu menggelora, sehingga bacaan-bacaan dari berbagai literatur mampu dilahap dengan begitu nikmatnya. Baik ketika masih di Madinah maupun di Irak, al-Syâfi'i begitu tekun mengkaji pemikiran Imam Malik bin Anas dan Imam Abû Hanifah, keduanya pemikir besar yang menjadi penggerak pemikiran di Madinah dan Irak. Al-Syâfíi dengan tekun menjadi seorang pemikir yang mampu membangun peradaban keilmuannya sendiri, tanpa harus taqlid 
dengan para gurunya. Kebebasan bacaan memberikan otonomi keilmuan yang tumbuh subur dalam pribadi seorang al-Syâfi'i.

Menurut Yudian, gerak yang sama juga dilakukan oleh al-Fârâbî yang sangat tekun dalam mengkaji filsafat Islam. Jasa-jasa al-Fârâbî dalam membangun peradaban filsafat di bumi Islam memberikan inspirasi besar bagi generasi Islam kemudian untuk memajukan peradaban dengan tekunnya. Al-Fârâbî juga prototipe pembaca yang sangat tekun, semua dilahap dengan penuh kenikmatan. Ia bukan saja seorang filosof, juga ahli dalam kajian fikih, sejarah, teologi, dan akhlak. Mereka tidak pernah berhenti dengan satu bidang kajian keilmuan, tetapi mampu "merampungkan" beragam disiplin. Ledakan iqra' menjadikan alFârâbî maestro yang disegani.

Menurut Yudian, spirit iqra' inilah yang juga dilakukan pemikir kontemporer dalam dunia Islam saat. Dengan Iqra', pemikir Islam kontemporer "berani” melakukan dekonstruksi dan rekontruksi dalam bangunan pemikiran kajian Islam. Dekonstruksi pemikiran lahir di berbagai tempat, bahkan tidak sedikit yang mengalami ketegangan dengan status quo yang masih konservatif. Yudian memotret seorang pemikir asal Sudan, Mahmud Muhammad Thoha. Pemikir yang mengangkat kembali relevansi ayat makkiyah itu memberikan terobosan besar ihwal urgensi hukum Islam yang sesuai dengan ruang dan waktu. Sayang, pemikiran Thoha justru disalah pahami, sehingga dia dianggap melenceng, dan akhirnya harus tunduk untuk dihukum mati.

Menurut Yudian, walaupun tragedi menyelimuti para pemikir tersebut, tetap saja energi iqra'begitu merembet dari satu generasi menuju generasi berikutnya. Justeru dengan tragedi itu malah membangkitkan semangat pencerahan. Generasi masa depan semakin yakin melakukan proses pembaharuan, sehingga warisan peradaban Islam tidak beku dan kaku dalam menghadapi tantangan kontemporer. Semua ini disadari oleh Yudian, sehingga dia begitu keras dalam belajarnya, sampai tergapai prestasi besar yang diraihnya, menjadi guru besar di Amerika Serikat. Dia juga mampu masuk di Universitas Harvard, kampus paling prestisius di dunia.

"Pengantar" ini semakin menarik karena Yudian menyuguhkan gerakan dalam membangun peradaban Islam masa depan. Di pesantren yang dikelolanya, Yudian melakukan revolusi pemikiran agar santrinya jangan hanya mampu menembus kampus Indonesia saja, melainkan disemangati untuk menembus kampus bergengsi di dunia. Jangan hanya menjadi guru besar di Indonesia saja, tetapi juga harus mampu menjadi guru besar di berbagai kampus bergengsi di Eropa. Pesantren yang dikelolanya menyediakan pendidikan dasar sampai menengah yang diharapkan mampu mencetak kader santri yang mempunyai nilai ujian nasional minimal 9,5, sebuah angka yang diharapkan santrinya masuk dalam berbagai kampus bergengsi. Ini sebuah lompatan gerakan agar warisan Islam tidak mandek dan jalan di tempat. Jihad ilmiah yang diinspirasikan penulis dalam buku ini mengajak pembaca untuk terus melakukan terobosan-terobosan penting dalam mencerahkan peradaban umat manusia. 


\section{Dinamika Pendidikan Islam di Asia Tenggara ${ }^{19}$}

Buku ini berjudul Dinamika Pendidikan Islam di Asia Tenggara yang ditulis oleh Haidar Putra Daulay dan diterbitkan oleh Rineka Cipta Jakarta pada Maret 2009 dengan ketebalan halaman 226. Buku ini adalah hasil penelitian penulis pada bulan Februari-Maret dan AgustusSeptember 2004 ke berbagai negara di Asia Tenggara, sebagai sampelnya adalah Malaysia, Singapura, Thailand, Brunei, Filipina dan Indonesia.

Buku ini terdiri atas delapan bab yang membahas mengenai sejarah pertumbuhan dan perkembangan pendidikan Islam di berbagai negara di Asia Tenggara seperti Malaysia, Singapura, Thailand, Brunei, Filipina dan Indonesia. Di samping itu, dibahas pula berbagai lembaga pendidikan Islam di negara-negara tersebut, pembaharuan pendidikan Islam padanya dan sistem pendidikan Islam. Dengan pertimbangan masyarakat Asia Tenggara adalah masyarakat religius di mana penduduk Islam terbesar di dunia berada di Asia Tenggara serta institusi pendidikan Islam tersebar di Asia Tenggara. Di samping itu, pendidikan Islam sangat adaptif terhadap perubahan dan kemajuan zaman dan pendidikan Islam terlaksana di negara yang penduduknya minoritas Islam.

\section{Jejak Pemikiran Pendidikan Islam}

Buku yang berjudul Pemikiran Pendidikan Islam yang ditulis oleh Syamsul Kumiawan dan Erwin Mahrus ini dan diterbitkan oleh Arruz Media di Yogyakarta berkenaan dengan pemikiran tokoh-tokoh pendidikan Islam sepanjang sejarah dan amat penting untuk dimiliki. Isi dari buku ini menjelaskan pasang surut perjalanan pemikiran kependidikan Islam, tidak akan pernah lepas dari interaksi akumulasi dengan peradaban-peradaban di sekitar perkembangan Islam waktu itu. Di mana perkembangan pemikiran kependidikan lebih dijiwai oleh semangat normatif dan historis. Dikatakan semangat normatif karena perkembangan pemikiran kependidikan dijiwai oleh ajaran dasar yang sumbernya al-Qur'an dan hadis. Sedangkan semangat historis adalah merupakan wujud respon terhadap berbagai persoalan hidup umat Islam di berbagai bidang kehidupan.

Dijelaskan bahwa sesuai dengan catatan sejarah, bahwa perkembangan pemikiran kependidikan Islam diawali pada saat Dinasti 'Abbasiyah yang mengalami renaissance, sehingga berakibat pemikiran kependidikan Islam nampak mengalami titik kulminasi. Sedang titik baliknya terjadi pada masa-masa dimana pemikiran-pemikiran para ilmuwan Islam, sebagian besar mengalami kemandegan (stagnation) sampai abad ke-14 yaitu munculnya Ibn Khaldûn. Hal ini dikarenakan sejak pada masa Nabi Muhammad SAW. sampai pada masa Dinasti Umayyah ilmu pengetahuan belum berkembang pesat, dan masih terpusat pada usaha pemenuhan kebutuhan untuk memahami prinsip-prinsip ajaran Islam sebagai

\footnotetext{
${ }^{19}$ Haidar Putra Daulay, Dinamika Pendidikan Islam di Asia Tenggara (Jakarta: Rineka Cipta, 2009).
} 
pedoman hidup yang waktu itu secara langsung telah dijawab dan diselesaikan oleh Nabi. Sedangkan pada masa Khulafâ' al-Râsyidîn dan Dinasti Umayyah lebih banyak disibukkan dengan pemecahan masalah politik dan perluasan wilayah Islam, dan belum sempat menggali dan mengembangkan ilmu pengetahuan, sehingga bisa dikatakan pada masa-masa itu patron ilmu pengetahuan belum dimiliki oleh umat Islam. Baru setelah zaman Abbasiyah, ilmu pengetahuan dalam berbagai disiplin berkembang.

Dijelaskan bahwa awal perkembangan ilmu dalam Islam dimulai dari perkenalannya dengan budaya Hellenisme, kemudian penerjemahan karya-karya klasik, ilmu pengetahuan dan filsafat Yunani, Syria, Sanskrit, dan bahasa Pahlevi ke dalam bahasa Arab yang berlangsung dari tahun 750-900 M, sejak masa al-Manshur (754-775 M), Harun al-Rasyid (786-809 M), dan sampai puncaknya pada masa al-Ma'mun (813-833 M). Abad-abad ini merupakan abad penerjemahan yang meletakkan tonggak abad aufklarung Islam kawasan Timur, dan bertahan hingga melampaui abad kesepuluh dan kesebelas. Walaupun setelah itu, ada gejala penurunan, akan tetapi sampai abad ketiga belas perkembangan ilmu pengetahuan masih ada dan baru benar-benar mengalami stagnasi setelah penghancuran total oleh Hulagu Khan (1258 M) yang juga diikuti oleh jatuhnya orang-orang Muwahid di Spanyol (1268 M). Kalau dicermati di masa kemunduran itu sesungguhnya masih muncul ilmuwan Muslim yaitu Ibn Khaldûn (1332-1406 M) sebagai ahli teori sejarah. Sejak inilah stagnation betulbetul terjadi dan ditandai lagi dengan jatuhnya dunia Islam ke tangan Kolonial Eropa, yang mengakibatkan ilmu Islam terbatas pada ilmu agama dan muncullah sekuler.

Baru pada abad ke-19 atau abad kebangkitan Islam mulai ada respons terhadap ilmu pengetahuan modern dan termasuk filsafat, walaupun ada sikap-sikap yang antagonistik dan akomodatif. Dengan munculnya pelopor modernisasi di dunia Islam yaitu Sayyid Khan (1817-1898 M), orang India yang pertama meyakini perlunya penafsiran baru terhadap Islam, yaitu penafsiran bebas modern dan maju. Bahkan menimbulkan gejala yang sering ditunjukkan oleh pengamat Barat baik secara netral, tidak senang maupun rasa takut, akan gejala kebangkitan Islam. Naluri manusia untuk selalu ingin tahu itulah yang menjadikan pangkal tolak perkembangan ilmu pengetahuan. Pemikiran kependidikan Islam mulai muncul, kendati pun masih dalam bentuk "embrionik", dan berkembang hingga dewasa ini.

Buku berjudul Jejak Pemikiran Tokoh Pendidikan Islam, dengan segala kekurangan dan keterbatasannya, studi dan penelitian buku ini dilakukan dengan tujuan mengelaborasi dan menjelaskan mengenai konsep pendidikan yang dilontarkan para pemikir-pemikir pendidikan di kalangan umat Islam. Buku ini mengungkapkan pokok-pokok pemikiran pendidikan Islam sejak permulaannya, pada masa Nabi Muhammad SAW., sampai pada masa pembaruan pendidikan yang dilakukan setelah masa Nabi Muhammad SAW, yaitu masa Khulafâ' al-Râsyidîn, Bani Umayyah, Bani 'Abbasiyah, dan seterusnya, juga hasil para pemikir pendidikan Islam terkemuka seperti al-Ghazâlî dan Ibn Khaldûn. Ditambah lagi, hasil pemikiran para tokoh dari tanah air yang tidak sedikit juga ikut andil memberikan kontribusinya dalam bidang pendidikan, seperti KH. Ahmad Dahlan, KH. Hasyim Asy‘ari, dan Basiuni Imran (tokoh dari Sambas, Kalimantan Barat). 
Penelusuran kembali pemikiran pendidikan di kalangan umat Islam memang amat diperlukan. Karena hal ini setidaknya mengingatkan kembali khazanah intelektual yang pernah dimiliki oleh umat Islam di masa lalu. Kesadaran historis ini pada gilirannya akan memelihara kesinambungan atau kontinuitas keilmuan khususnya dalam kajian tentang pendidikan Islam. Pemikiran-pemikiran kependidikan dalam Islam dan pemikiran para tokoh dalam bidang pendidikan ini juga bisa dijadikan sebagai bahan pertimbangan dalam mengambil keputusan atas kebijakan sesuai dengan kondisi zaman saat ini, sehingga hasil atau pokok-pokok pikiran para ahli ini patut dikaji kembali dalam rangka membenahi sistem pendidikan Islam, terutama di negeri Indonesia tercinta ini.

\section{Jaringan Ulama Timur Tengah dan Kepulauan Nusantara Abad 17 dan 18 Masehi}

Buku ini merupakan karya monumental dari Prof. Dr. Azyumardi Azra, MA, yang pernah menjadi Rektor UIN Syarif Hidayatullah, Jakarta. Buku ini termasuk buku terbaik dalam lektur pendidikan Islam di era modern.

\section{Biografi Penulis}

Azyumardi Azra, lahir di Lubuk Alung, Padang Pariaman, Sumatera Barat, 4 Maret 1955. Ia adalah akademisi Muslim asal Indonesia. Ia juga dikenal sebagai cendekiawan Muslim. Azyumardi terpilih sebagai Rektor UIN Syarif Hidayatullah Jakarta pada 1998 dan mengakhirinya pada 2006. Pada tahun 2010, dia memperoleh titel Commander of the Order of British Empire, sebuah gelar kehormatan dari Kerajaan Inggris. Dengan gelar ini, maka ia adalah orang pertama di luar warga negara anggota Persemakmuran yang boleh mengenakan Sir di depan namanya.

Azyumardi memulai karier pendidikan tingginya sebagai mahasiswa sarjana di Fakultas Tarbiyah IAIN Jakarta pada tahun 1982. Atas bantuan beasiswa Fullbright, ia mendapatkan gelar Master of Art (MA) pada Departemen Bahasa dan Budaya Timur Tengah, Columbia University tahun 1988. Ia memenangkan beasiswa Columbia President Fellowship dari kampus yang sama, tapi kali ini Azyumardi pindah ke Departemen Sejarah, dan memperoleh gelar MA pada 1989. Pada 1992, ia memeroleh gelar Master of Philosophy (M.Phil) dari Departemen Sejarah, Columbia University tahun 1990, dan Doctor of Philosophy Degree dengan disertasi berjudul The Transmission of Islamic Reformism to Indonesia: Network of Middle Eastern and Malay-Indonesian 'Ulama in the Seventeenth and Eighteenth Centuries. Tahun 2004, disertasi yang sudah direvisi diterbitkan secara simultan di Canberra (Allen Unwin dan AAAS), Honolulu (Hawaii University Press), dan Leiden, Belanda (KITLV Press).

Kembali ke Jakarta, pada tahun 1993 Azyumardi mendirikan sekaligus menjadi pemimpin redaksi Studia lslamika, sebuah jurnal Indonesia untuk studi Islam. Pada tahun 1994-1995, ia mengunjungi Southeast Asian Studies pada Oxford Centre for Islamic Studies, 
Oxford University, Inggris, sambil mengajar sebagai dosen pada St. Anthony College. Azyumardi pernah pula menjadi profesor tamu pada University of Philippines, Philipina dan University Malaya, Malaysia; keduanya pada tahun 1997. Selain itu, ia adalah anggota dari Selection Committee of Southeast Asian Regional Exchange Program (SEASREP) yang diorganisir oleh Toyota Foundation dan Japan Center, Tokyo, Jepang antara tahun 1997-1999. Sejak Desember 2006, ia menjabat Direktur Pascasarjana UIN Syarif Hidayatullah, Jakarta. Sebelumnnya, sejak tahun 1998 hingga akhir 2006, Azyumardi Azra adalah Rektor UIN Syarif Hidayatullah Jakarta. Ia pernah menjadi wartawan Panji Masyarakat (1979-1985), Dosen Fakultas Adab dan Fakultas Tarbiyah IAIN Syarif Hidayatullah, Jakarta (1992-sekarang), Guru Besar Sejarah Fakultas Adab IAIN Jakarta, dan Pembantu Rektor I IAIN Syarif Hidayatullah, Jakarta (1998). Ia juga merupakan orang Asia Tenggara pertama yang diangkat sebagai Professor Fellow di Universitas Melboume, Australia (2004-2009), dan anggota Dewan Penyantun (Board of Trustees) International Islamic University Islamabad Pakistan (2004-2009).

Azyumardi Azra dikenal sebagai Profesor yang ahli sejarah, sosial dan intelektual Islam. Ketika menjadi Rektor pada lnstitut Agama Islam Negeri (IAIN) Syarif Hidayatullah Jakarta, ia melakukan terobosan besar terhadap institusi pendidikan tersebut. Pada Mei 2002, IAIN tersebut berubah nama menjadi Universitas Islam Negeri (UIN) Syarif Hidayatullah Jakarta. Hal ini merupakan kelanjutan ide Rektor terdahulu, Prof. Dr. Harun Nasution, yang menginginkan lulusan IAIN haruslah orang yang berpikiran rasional, modern, demokratis, dan toleran. Pada awalnya, Azyumardi tidak berobsesi atau bercita-cita menggeluti studi keislaman. Sebab, ia lebih berniat memasuki bidang pendidikan umum di IKIP. Akan tetapi, atas desakan ayahnya, ia masuk ke IAIN sampai akhirnya ia dikenal sebagai tokoh intelektual Islam Indonesia. Ia lahir dari ayah Azikar dan Ibu Ramlah. Pada 2006, posisinya sebagai Rektor resmi digantikan oleh Prof. Dr. Komaruddin Hidayat. Dalam rapat senat yang ia pimpin sendiri, Komaruddin Hidayat terpilih meng-gantikannya dengan mengalahkan dua kandidat lainnya.

Sejumlah karya Azra antara lain Jaringan Ulama (1994), Pergolakan Politik Islam (1996), Islam Reformis (1999), Konteks Berteologi di Indonesia (1999), Menuju Masyarakat Madani (1999), Pendidikan Islam: Tradisi dan Modernisasi Menuju Milenium Baru (1999), Esei-esei Pendidikan Islam dan Cendekiawan Muslim (1999), Renaisans Islam di Asia Tenggara (1999), Islam Substantif (2000), Historiografi Islam Kontemporer: Wacana, Aktualitas dan Aktor Sejarah (2002), Paradigma Baru Pendidikan Nasional: Rekonstruksi dan Demokratisasi (2002), Reposisi Hubungan Agama dan Negara (2002), Menggapai Solidaritas: Tensi antara Demokrasi, Fundamentalisme, dan Humanisme (2002), Islam Nusantara: Jaringan Global dan Lokal (2002), dan Surau: Pendidikan Islam Tiadisional dalam Transisi dan Modernisasi (2003). Azra mendapat penghargaan sebagai penulis paling produktif dari Penerbit Mizan Bandung pada tahun 2002. 


\section{Deskripsi dan Analisis}

Buku ini berupaya menjawab beberapa masalah pokok. Pertama, bagaimana jaringan keilmuan terbentuk di antara ulama Timur Tengah dengan murid-murid Melayu-Indonesia? Bagaimana sifat dan karakteristik jaringan itu? Apakah ajaran atau tendensi intelektual yang berkembang dalam jaringan? Kedua, apa peran ulama Melayu-Indonesia dalam transmisi kandungan intelektual jaringan ulama itu ke Nusantara? Bagaimana modus transmisi itu? Ketiga, apa dampak lebih jauh dari jaringan ulama terhadap perjalanan Islam di Nusantara.

Berbeda dengan studi-studi yang ada tentang Islam di Indonesia pra-abad ke -19, yang biasanya mendasarkan pembahasannya pada sumber-sumber Barat dan lokal, Azyumardi Azra berusaha semaksimal mungkin menggali dan menggunakan sumber-sumber berbahasa Arab. Tampaknya inilah buku pertama yang menggunakan sumber-sumber Arab secara ekstensif dalam pengkajian yang berkenaan dengan sejarah pembaruan pemikiran Islam di Indonesia.

Buku ini disusun menjadi 5 bab. Dalam bab pertama, dibahas mengenai teori masuknya Islam ke Indonesia serta analisis mengenainya serta hubungan awal Muslim nusantara dengan Timur Tengah. Dalam bab kedua, dibahas lebih gamblang mengenai jaringan ulama Haramayn pada abad ke 17, di mana pada waktu itu dua tanah haram tersebut berperan sebagai pusat intelektual di dunia Islam di mana banyak ulama yang berkumpul mengajar dan berinteraksi di sana dengan berbagai pelajar yang juga datang dari berbagai penjuru dunia. Dalam bab ketiga, dibahas mengenai transmisi gagasan pembaruan dalam jaringan ulama dan penyebarannya ke dunia Islam yang lebih luas khususnya pada abad ke 18 . Dalam bab keempat, dibahas beberapa tokoh penting sebagai perintis gerakan pembaruan Islam di Nusantara di mana mereka ini adalah ulama Indonesia yang berada pada jaringan abad ke 17. Mereka adalah Nûr al-Dîn al-Rânîrî, 'Abd Ra'uf al-Sinkili dan Muhammad Yûsuf al-Maqassari. Dalam bab kelima, dibahas mengenai jaringan ulama dan pembaruan Islam di wilayah Melayu-Indonesia abad ke 18 seperti al-Palimbani, al-Banjarî, dan Dawud alPatanî.

Secara garis besar, referensi buku ini terdiri dari sumber primer yang diambil dari manuskrip kuno, buku cetakan, disertasi, dan makalah. Kedua sumber sekunder yang diambil dari buku dan artikel yang jumlahnya sangat banyak. Kiranya buku merupakan kajian yang dapat menggambarkan sejarah pendidikan Islam abad ke 17 dan 18, karena memang referensinya yang begitu banyak menggunakan buku klasik yang berbahasa Arab, apalagi manuskrip-manuskrip yang memang karya dari ulama-ulama yang hidup pada abad ke 17 dan 18 yang langsung ikut berperan dalam jaringan tersebut. Namun informasi yang begitu banyak mengenai jaringan tersebut ditawarkan dalam susunan bahasa yang kurang baik yang kadang banyak menggunakan istilah Arab maupun Barat membuat buku ini sukar dicerna oleh kalangan awam. 
Buku ini menjelaskan bahwa pembaruan sudah dimulai dari abad ke 17 dan bukan pada abad ke 19, namun konteks pembaruan di sini terkait dengan penyelarasan antara tasawuf dan syariat serta merubah tasawuf yang berwajah pasif kepada tasawuf yang berciri aktif dan dinamis yang dikenal dengan neo sufisme. Gerakan neo sufisme inilah produk dari jaringan ulama tersebut di mana yang menjadi cirinya adalah telaah terhadap hadis dan tarekat. Dari telaah hadis, para ulama terinspirasi dan wawasan mengenai cara memimpin masyarakat Muslim menuju rekonstruksi sosio-moral. Gerakan pembaruan tersebut ada yang bersifat radikal seperti gerakan Wahabi dan 'Utsman bin Fudi, namun pada umumnya banyak pula ulama yang memilih pendekatan evolusioner. Sementara itu, gerakan Kaum Padri di Nusantara terinspirasi dari gerakan radikal Wahabi.

Salah satu kritikan terhadap buku ini adalah bahwa buku ini tidak hanya membahas masalah perkembangan pendidikan Islam pada abad 17 dan 18, tetapi pembahasannya juga melebar ke berbagai aspek seperti teologi, tasawuf, politik, dan budaya sosial, sehingga pada saat membacanya, pembaca digiring ke berbagai permasalahan yang kelihatnnya tidak terkait dengan pendidikan.

\section{Menyingkap Zaman Keemasan Islam}

Buku ini berjudul Menyingkap Zaman keemasan Islam ditulis oleh Hasan Asari dan diterbitkan di Bandung oleh Cipta Pustaka Media pada tahun 2007 terdiri dari 266 halaman.

\section{Biografi Penulis}

Hasan Asari lahir di Hajoran Simaninggir, pada tanggal 2 November 1964. Setelah menyelesaikan pendidikannya di Pesantren Tarbiyah Islamiyah Hajoran, Labuhan Batu, Sumatera Utara, ia melanjutkan pendidikannya di jurusan PBA Fakultas Tarbiyah IAIN Sumatera Utara Medan (1988). Kemudian melanjutkan studinya di Institute of Islamic Studies McGill University pada tahun 1993 memperoleh beasiswa dari Canada International Development Agency. Kemudian ia memperoleh gelar Doktor dari IAIN Jakarta pada tahun 2000. Kini ia menjabat sebagai Pembantu Rektor I di UIN Sumatera Utara Medan, dan Profesor dalam bidang Sejarah Pendidikan Islam pada Fakultas Ilmu Tarbiyah dan Keguruan UIN Sumatera Utara.

Hasan Asari telah menghasilkan beberapa karya. Di antara karyanya adalah Menyingkap Zaman keemasan Islam: Studi tentang Lembaga-lembaga Pendidikan (Bandung: Mizan, 1994), Nukilan Pemikiran Islam Klasik: Gagasan Pendidikan al-Ghazali (Yogyakarta: Tiara Wacana, I999), Etika Akademis dalam Islam (PPS IAIN Jakarta, 2000), Modernisasi Islam: Tokoh, Gagasan dan Gerakan (Bandung: Ciptapustaka Media, 2002), dan Menguak Sejarah Mencari 'Ibrah: Risalah Sejarah Sosial-Intelektual Muslim Klasik (Bandung: Ciptapustaka Media, 2006). 


\section{Deskripsi dan Analisis}

Buku karya Hasan Asari ini terdiri atas 6 bab yang mengkaji mengenai zaman keemasan Islam. Dalam bab pertama, penulis mendeskripsikan kegiatan ilmiah pada masa pra-Islam baik di Jazirah Arabia maupun di luar Jazirah. Dalam bab kedua, membahas sebuah lembaga pendidikan Islam yaitu Kuttâb. Dalam bab ketiga, dua lembaga pendidikan lainnya yaitu Masjid dan Masjid Khan serta perannya sebagai lembaga pendidikan. Dalam bab keempat, dibahas madrasah sebagai lembaga pendidikan Islam par excellence sebagai pusat perkembangan peradaban Islam. Dalam bab kelima, dibahas Dâr al-Qur'an dan Dâr al-Hadits sebagai lembaga pengkajian al-Qur'an dan Hadis. Dalam bab keenam, penulis memaparkan tiga pusat pendidikan kaum sufi yaitu, ribath, zawiyah dan khanqah. Dalam bab ketujuh, penulis menjelaskan beberapa lembaga pendidikan Islam yang difungsikan dalam pengembangan sains seperti Bayt al- $\underline{H i k m a h}$, perpustakaan, observatorium, dan rumah sakit. Penulis menutup buku ini dengan sebuah epilog mengenai pendidikan Islam kontemporer dan pencarian model kelembagaan. Secara garis besar, buku ini memiliki referensi sejumlah 97 buah, di mana 37 buku darinya adalah literatur Arab baik klasik maupun modern. Dengan demikian, penulis masih banyak menggunakan literatur Barat dan lokal.

Buku ini memfokuskan pembahasannya pada sejarah lembaga-lembaga pendidikan Islam pada masa klasik seperti kuttâb sebagai lembaga pendidikan dasar, masjid, masjid khan yang merupakan masjid yang memiliki asrama pelajar yang berfungsi sebagai lembaga pendidikan menengah dan tinggi; dan madrasah atau universitas yang merupakan lembaga pendidikan tingkat tinggi yang lebih terkoordinir. Madrasah merupakan bentuk evolusi dari masjid dan masjid khan. Ada juga lembaga khusus yang mengkaji al-Qur'an dan hadis yang dikenal dengan Dâr al-Qur'ân dan hadis begitu juga lembaga pendidikan sufi dan lembaga pengembangan sains.

Akan tetapi, buku ini kurang menyinggung masalah jaringan ulama di berbagai wilayah Islam dan bagaimana perkembangan pendidikan Islam pada masa klasik seperti masalah karya-karya intelektual Islam dan sumbangsih mereka pada masa keemasan Islam, dan pada dunia khususnya atau berbagai ide-ide pendidikan yang kiranya dapat diaplikasikan pada masa kontemporer. Artinya, sejarah merupakan cerminan untuk lebih dapat menatap masa depan yang lebih cerah dan mengambil i'tibar darinya dengan meninggalkan segala kekurangan yang terjadi pada masa lampau dan mengambil berbagai nilai-nilai positif yang dapat dikembangkan pada konteks kekinian. Akan tetapi, buku ini diakui sebagai referensi yang paling representatif bagi sejarah lembaga pendidikan Islam di mana penulisnya menyadur langsung dari berbagai karya-karya ulama klasik, dan menulisnya dengan begitu sistematis dengan bahasa yang baik.

\section{Penutup}

Sejarah Pendidikan Islam adalah cabang ilmu pengetahuan mengenai pertumbuhan 
dan perkembangan pendidikan Islam dari segi ide, konsep, lembaga operasionalisasi dari sejak zaman Nabi Muhammad SAW. sampai sekarang. Kegunaan sejarah pendidikan meliputi dua aspek yaitu kegunaan yang bersifat umum dan yang bersifat akademis. Pertama, ilmu sejarah berfungsi sebagai cermin dengan berusaha menafsirkan pengalaman masa lampau manusia dalam berbagai kegiatan. Akan tetapi, sejalan dengan perkembangan bahwa tidak semua kegiatan manusia berjalan mulus terkadang menemukan rintangan-rintangan tertentu sehingga dalam proses kegiatannya mendapat sesuatu yang tidak diharapkan, maka perlu bercermin. Dengan kata lain, mengambil pelajaran dari kejadian-kejadian masa lampau sehingga târîkh itu bagi masa depan menjadi cermin dan dapat diambil manfaatnya khususnya bagi perkembangan pendidikan Islam. Kedua, sebagai pembanding suatu peristiwa yang berlangsung dari masa ke masa, tentu memiliki kesamaan dan kekhususan. Dengan demikian, hasil proses pembanding antara masa silam, sekarang, dan masa mendatang diharapkan dapat memberi andil bagi perkembangan pendidikan Islam, karena sesungguhnya târîkh itu menjadi cermin perbandingan bagi masa mendatang. Ketiga, sebagai perbaikan, setelah berusaha menafsirkan pengalaman masa lampau manusia dalam berbagai kegiatan, manusia berusaha pula untuk memperbaiki keadaan yang sebelumnya kurang konstruktif menjadi lebih konstruktif.

Bagian terdahulu telah menjelaskan delapan buku dalam sejarah pendidikan Islam di Indonesia. Buku pertama membahas sejarah pendidikan Islam secara umum mulai dari periode Rasul sampai Indonesia pada masa Orde Lama. Buku kedua membahas paradigma klasik pendidikan Islam hingga kontemporer. Buku ketiga mengkaji mengenai pertumbuhan dan pembaharuan pendidikan Islam. Buku keempat berusaha untuk merekonstruksi kembali pendidikan Islam yang benar. Buku kelima membahas dinamika pendidikan Islam secara luas tidak hanya di Indonesia, tetapi juga di Asia Tenggara. Buku keenam mengkaji mengenai berbagai pemikiran tokoh pendidikan Islam. Buku ketujuh mengulas jaringan ulama Timur Tengah dan kepulauan Nusantara dalam membentuk pendidikan yang Islami. Buku kedelapan mengulas zaman keemasan Islam dalam berbagai bidang, khususnya bidang pendidikan. Dari aspek konten, seluruh buku ini bermanfaat untuk menata ulang pendidikan yang Islami di Indonesia, dan dapat memberikan kontribusi bagi kemajuan pendidikan Islam di masa mendatang.

\section{Pustaka Acuan}

Arief, Armai. Sejarah Pertumbuhan dan Perkembangan Lembaga Pendidikan Islam Klasik. Bandung: Percetakan Angkasa, 2005

Asrohah, Hanun. Sejarah Pendidikan Islam. Jakarta: Logos Wacana Ilmu, 2001.

Daulay, Haidar Putra. Dinamika Pendidikan Islam di Asia Tenggara. Jakarta: Rineka Cipta, 2009.

Daulay, Haidar Putra. Sejarah Pertumbuhan dan Pembaruan Pendidikan Islam di Indonesia. Jakarta: Kencana Perdana Media Group, 2007. 
Departemen Agama. Rekontruksi Sejarah Pendidikan Islam di Indonesia. Jakarta: Departemen Agama RI, 2005.

Hasbullah. Sejarah Pendidikan Islam di Indonesia. Jakarta: RajaGrafindo Persada, 1995.

Mustafa. A., Sejarah Pendidikan Islam di Indonesia, Bandung: Pustaka Setia, 1999.

Nizar, Syamsul. Sejarah Pendidikan Islam. Jakarta: Kencana Perdana Media Group, 2007.

Rukiati, Enung K. Sejarah Pendidikan Islam di indonesia. Bandung: Pustaka Setia, 2006.

Team Dosen Fakultas Tarbiyah UIN Malang. Pendidikan Islam dari Paradigma Klasik Hingga Kontemporer. Malang: UIN MALANG Press, 2009.

Wahyudi, Yudian. Islam: Percikan Sejarah,Filsafat, Politik, Hukum dan Pendidikan Yogyakarta: Pesantren Nawesea Press, 2011.

Zuhairini, et al. Sejarah Pendidikan Islam. Jakarta : Bumi Aksara, I997. 